Turning specifically to the design of information systems, the authors posit that traditional concepts of systems analysis have been inadequate to the task because information problems tend to be "Wicked Problems." The properties associated with "Wicked Problems" include the following: there is no definitive solution to the problem; problem formulation is identical with problem solving; wicked problems have no stopping rule, for improvement is always possible; solutions cannot be categorized as right or wrong, but only as "good" or "bad" in varying degrees depending upon the viewpoint of the evaluator; and there is no right to be wrong. Opportunities for experimentation and trial and error solutions do not exist.

The authors describe a variety of methods and techniques to assist in the design of information systems which they call "systems research of the 2nd generation." The methodology requires the joint participation of potential users as well as operators of the information system in all stages of design and implementation. The structured approach is an educational process and insures that competing demands (e.g., exhaustiveness vs. costs) are recognized and compromised in a rational fashion. As a theoretical model the technique unquestionably has great merit; but it demands a level of leisure, cooperation, and rationality seldom encountered in the real world. Still, information systems designers would be well advised to consider the well-documented failures of the traditional approaches before dismissing this procedure as too theoretical.-Robert L. Burr, Director, Crosby Library, Gonzaga University, Spokane, Washington.

\section{Turner, Eric G. The Typology of the Early}

Codex. Haney Foundation Series, Publ. 18. Philadelphia: University of Pennsylvania Press, 1977. 188p. \$25. LC 7510125. ISBN 0-8122-7696-5.

In this volume, which originated in a series of lectures delivered at the University of Pennsylvania in the spring of 1971, E. G. Turner, professor of papyrology at the University of London, investigates the bibliographical form of the surviving codices from the ancient world. The codex form in manuscript made its first appear- ance in the second century A.D. when leaves on papyrus or vellum were first placed between two covers rather than in a roll. Turner confines his examination to this early period through the sixth century and traces the early stages of the development of the format of the book.

In this pioneering study, Professor Turner has examined more than 1,000 manuscripts and has formed a series of tables where similar manuscripts are grouped together based upon dimension, papyrus or vellum material, the format of the text, and paleographical evidence. He has examined the majority of the manuscript fragments personally and carefully gives sources for his information for the other manuscripts. The tables of series and groupings are distributed throughout the text. A full discussion of these manuscripts and a review of the literature concerning each one is included. The second half of this volume consists of a table of eighty-three pages. It is a consolidated list of the codices studied, giving in tabular form in columns the basic information about the codices cited in the text. Each is identified by a serial number that serves to lead the reader quickly from the text to the table when a manuscript is discussed. A list of monographs and journals consulted precedes the text.

Professor Turner, a distinguished papyrologist and paleographer, has published a number of monographs and articles on books in antiquity. In this volume he has carefully pieced together his evidence from the extant fragments to create hypotheses that can aid in dating early codices and in tracing their development in a coherent manner. Considering the fragmentary and fragile nature of these manuscripts scattered throughout the Western world, his undertaking has been considerable. His hypotheses, while by the very nature of the objects studied tentative, are built upon the evidence gathered and are indeed impressive. They shed much light on the format and development of the earliest books in codex form.

This book will no doubt be purchased by all research libraries for the use of their classical scholars, and one hopes that library schools as well will want this study in descriptive bibliography for it is a significant contribution to the literature on the 


\title{
The Correspondence of the Three William Byrds of Westover, Virginia, 1648-1776
}

\author{
Edited By Marion Tinling
}

Virginia Historical Society Documents. 2 volumes, $\$ 32.50$

860 pp. (approx.), illus., tables, index. ISBN 0-8139-0669-5.

This is the definitive edition of the correspondence of the first three generations of William Byrds. The lives of these men, reflected in the letters of each, span the colonial period from the beginning of westward expansion until the Revolution. All the letters are complete and accurate transcriptions from the original manuscripts. Marion Tinling includes many letters previously unknown and places in proper chronological order those that have appeared separately in journals. Historians will welcome, as well, the full genealogical details about the Byrd family, along with biographical information that corrects many of the traditional myths about the Byrds. Countless other persons and places are also identified.

\section{A Pagan Prophet: William Morris \\ Charlotte Oberg}

192 pp. (approx.), illus., index. $\$ 13.95$

This sensitive and well-researched study argues convincingly that William Morris's narrative poetry and prose, rather than being escapist as they are usually described, represent his abiding conviction that art must be intrinsically related to life. Charlotte Oberg analyzes all the major works in the vast oeuvre of Morris. Her critical exploration reflects both firsthand manuscript study and a discussion of recent works in cultural anthropology and theories of myth.

\section{Business Ethics Bibliography}

$$
\text { 1971-1975 }
$$

\section{Donald G. Jones \\ $\mathrm{xx}, 207$ pp., index. ISBN 0-8139-0711-x. \$13.95}

This is a guide to studies published in the United States between 1971 and 1975, with selective annotation. The items cited cover the full range of subject matter, from personal integrity and the private ethics of executives to the wider, more complex issues of business and society relations. This bibliography is particularly valuable today because self-criticism, internal pressure to raise standards of conduct, and sensitivity to social responsibilities are increasingly becoming a part of today's business world. The book is a continuation of Daniel L. Gothie's A Selected Bibliography of Applied Ethics in the Professions, 1950-1970. (Virginia, \$4.75)

\section{University Press of Virginia}


history of the book.-Susan G. Swartzburg, Rutgers University Library, New Brunswick, New Jersey.

\section{Wright, H. Curtis. The Oral Antecedents} of Greek Librarianship. Foreword by Jesse H. Shera. Afterword by H. J. de Vleeschauwer. Provo, Utah: Brigham Young Univ. Pr., 1977. 237p. \$19.95. LC 77-73645. ISBN 0-8425-0623-3.

Librarians should not be deterred by the nondescript title, especially since so little scholarly research exists on the historical roots of the profession. The Oral Antecedents of Greek Librarianship seeks to fill a significant gap in the literature of librarianship. Wright attempts to deal with the antecedents of the Alexandrian library movement by focusing on the transition of classical civilization from an oral to a written tradition. Here, the author believes, can be found the origins of the library. This hypothesis is intriguing and entitles Wright to take his reader on a historical journey that recounts the function of information in classical society from preliterate times to classical Greece.

On the way, he introduces several unusual observations, some of which relate directly to his theme, others of which digress from it. One strong observation compares Homer to the librarian in terms of the information function of each within their societies-a unique argument that is well defended. Another observation of considerable merit details the heavy influence Oriental bibliographic methodology had on the Greeks. A third observation, however, involves Wright's defense of the "inventionist" against the "evolutionist" theory of writing. This one makes for a nice story, but hardly worth the lengthy effort in terms of his theme.

Of particular concern to this reviewer is Wright's heavy reliance on a few secondary sources, especially the works of S. H. Butcher, Rudolph Pfeiffer, and Chester G. Starr. It is obvious the author bought the ideas of all three, but his hopes that lengthy quotes from their works will serve to convince his own readers fall short of their mark. This is especially true for chapter Four, where Pfeiffer is referred to or quoted in nearly half the 246 footnotes.

The writing style is frequently burden- some (especially in chapter One, "The Metaphysics of Information"), and the organization occasionally loose. Shera's Foreword is good, but de Vleeschauwer's essay has already appeared in Toward a Theory of Librarianship: Papers in Honor of Jesse Hauk Shera, edited by Conrad Rawski (Metuchen, N.J.: Scarecrow, 1973). Taken together, the Foreword, Afterword, and text cover the subject; but a definitive study awaits the scholar who will put more stock in primary sources and be less influenced by second-party interpretations.-Wayne A. Wiegand, College of Library Science, University of Kentucky.

Kehr, Wolfgang; Neubauer, Karl Wilhelm; and Stoltzenburg, Joachim, eds. Zur Theorie und Praxis des modernen Bibliothekswesens. München: Verlag Dokumentation, 1976. 3v. DM 160. LC 77463478.

German librarianship, like its counterpart in the United States, has undergone a decade and a half of rapid growth and change. This handbook represents an attempt to inform German librarians and educators of new theory and practice, organizational reforms, and new technology in the library profession. In translation its title reads $O n$ the Theory and Practice of Modern Librarianship; and its three volumes treat social aspects, technological aspects, and administrative aspects.

The editors, exercising the principle of "limited variety," have compiled three volumes of essays on the state of the artrecent developments, current problems, and future trends in German librarianship and, where appropriate, have included information about librarianship in other countries as well.

Written by noted German librarians and educators, these essays provide a wealth of current information on such topics as public relations, research in library use, library instruction, professional image and education, electronic data processing developments, automation of technical processes, audiovisual media, library building planning, cost-effectiveness studies, management theory, personal leadership styles, and library statistics in German public and research libraries.

Though some unevenness of style and 